\title{
Penggunaan Terapi Komplementer dalam Modern Wound Dressing pada Pasien dengan Luka Diabetes: Literature Review
}

\author{
Hesti Kusumastuty ${ }^{1}$, Nur Setiawati Dewi ${ }^{1 *}$ \\ ${ }^{1}$ Departemen Keperawatan, Fakultas Kedokteran, Universitas Diponegoro, Semarang, Indonesia \\ nurse.tiawatidewi@fk.undip.ac.id
}

\begin{abstract}
Introduction: The number of diabetes mellitus sufferers with diabetic ulcus continues to increase. Wound care using conventional methods is no longer effective. Selection of the right wound care can effectively improve wound healing and reduce the financial burden on serving the clientst. The aim of this literature review was to explore the efficacy of wound healing with modern wound care management in diabetic ulcers.

Methods: A literature search using the Google Scholar database, Springer Link, Clinical Key, Pubmed and Proquest found 20 journal articles that match the criteria.

Results: The majority of research results show the effectiveness of using modern clothing to heal diabetic wounds.

Conclusion: Modern wound care dressings with the addition of complementary therapies have shown a more significant effect in accelerating diabetic wound healing.
\end{abstract}

Keywords: Complementary Therapy, Diabetic Ulcer, Modern Dressing, Wound Care.

\begin{abstract}
Abstrak
Pendahuluan: Jumlah penderita diabetes mellitus dengan luka diabetic terus meningkat. Perawatan luka denga metode konvensional sudah tidak efektif. Pemilihan perawatan luka yang tepat dapat secara efektif meningkatkan penyembuhan luka dan berpotensi mengurangi morbiditas dan beban keuangan yang dialami pasien. Tujuan dari literature review ini adalah untuk mengevaluasi efektifitas penyembuhan luka dengan manajemen modern wound dressing pada ulkus diabetik.

Metode: Pencarian literatur menggunakan database Google Scholar, Springer Link, Clinical Key, Pubmed dan Proquest telah menemukan 20 artikel jurnal yang sesuai dengan kriteria.

Hasil: Mayoritas hasil penelitian menunjukan efektifitas penggunaan modern dressing untuk kesembuhan luka diabetes.

Kesimpulan: Perawatan luka modern dressing dengan penambahan terapi komplementer menunjukan pengaruh yang lebih signifikan dalam mempercepat penyembuhan luka diabetik.
\end{abstract}

Kata Kunci: Luka Diabetik, Modern Dressing, Perawatan Luka, Terapi Komplementer.

\section{PENDAHULUAN}

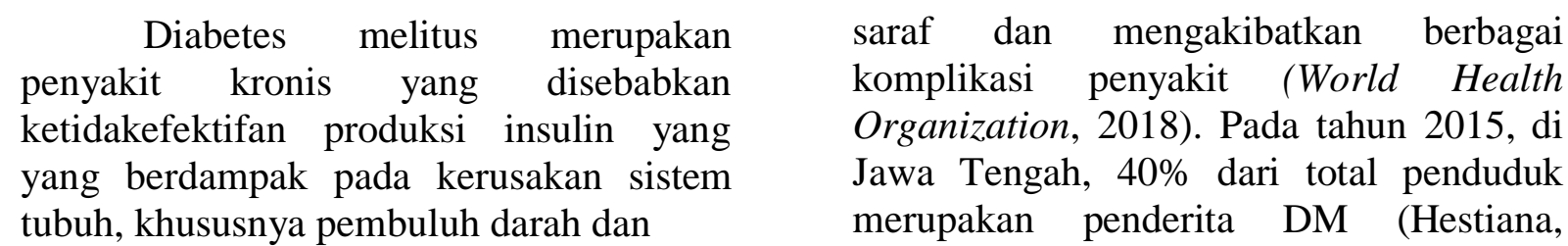


2017), dan Kota Semarang menempati urutan ketiga dari seluruh kabupaten/kota di Jawa Tengah (Anggriani, Hariani., \& Dwiyanti, 2019).

Meningkatnya jumlah penderita diabetes melitus menyebabkan tingginya kejadian komplikasi diabetes, salah satunya diabeticum foot ulcer (Handayani, 2016). Luka kaki diabetik terjadi pada kaki diabetisi karena adanya gangguan sirkulasi darah di kaki, gangguan persyarafan, dan adanya infeksi karena menurunnya imunitas tubuh (Kusumaningrum \& Asriningati, 2016).

Perawatan yang komprehensif pada ulkus diabetik akan meningkatkan potensi kesembuhan mencapai 90\%, (Kristiyaningrum, 2013). Teknik perawatan luka konvesional seringkali tidak efektif terhadap penyembuhan luka klien (Adriani \& Mardianti, 2016). Berdasarkan hal tersebut, peneliti tertarik untuk memperoleh gambaran penggunaan modern wound dressing pada klien dengan ulkus diabetik melalui studi literatur.

Penelitian sebelumnya mencatat bahwa modifikasi terapi modern dressing dan komplementer ozon pada pasien secara efektif mampu menurunkan kerusakan luka diabetik daripada hanya dengan menggunakan modern dressing saja (Megawati, Hakimi, \& Sumaryani, 2015). Penelitian terbaru mengenai manajemen perawatan luka sangat dibutuhkan untuk meningkatkan pengetahuan dan mengidentifikasi adanya kesenjangan dalam pengetahuan. Telaah literatur ini dilakukan untuk menambah pengetahuan perawatan luka diabetes dengan tujuan mengetahui gambaran manajemen modern wound dressing pada luka diabetik.

\section{METODE}

Penelitian menggunakan pendekatan literature review. Artikel dipilih berdasarkan kriteria yaitu 1) artikel berbahasa inggris atau berbahasa Indonesia dengan terindeks SINTA 1-6, publikasi 5-
10 tahun terakhir 2) artikel berbentuk full text.

Pencarian literatur menggunakan database Google Scholar, Springer Link, Clinical Key, Pubmed dan Proquest. Beberapa istilah atau kata kunci digunakan untuk mendapatkan artikel yang sesuai dengan topik dari literature review, antara lain menggunakan istilah "dressing", "perawatan luka", dan "luka diabetik" untuk menemukan artikel jurnal berbahasa Indonesia. Kata kunci yang digunakan untuk menemukan artikel jurnal dalam bahasa Inggris yaitu "wound dressing", "woundcare", dan "diabetic foot ulcer".

Hasil pencarian didapatkan 171 artikel dengan kriteria di atas. Selanjutnya peneliti mengeluarkan artikel yang tidak termasuk dalam "modern dressing", "modern woundcare", "modern wound dressing", dan "perawatan luka modern." Hasil seleksi kedua, sebanyak 76 artikel berhasil didapatkan. Tahap selanjutnya, peneliti mengeluarkan artikel yang tidak full-text dan atau artikel full-text namun tidak berbahasa Inggris/Bahasa Indonesia. Total artikel yang ditelaah adalah 20 artikel.

\section{HASIL}

Pengelompokan data diawali dengan menyintesis dua puluh artikel jurnal terkait. Kemudian artikel dibuat ringkasan meliputi nama penulis, tahun terbit jurnal, tujuan, metode, sampel, temuan, kesamaan, keunikan. Selanjutnya, sintesis dijelaskan dengan menggunakan matriks sintesis (synthesis matrix) untuk menggabungkan dan menglasifikasikan hasil penelitian yang berbeda dari beberepa artikel dan mengkombinasikan dengan elemen yang berbeda untuk mendapatkan kesimpulan dari artikel yang dipilih secara umum. Secara detail, proses ini dijelaskan dalam tabel 1 dan tabel 2. 


\section{PEMBAHASAN}

Menurut hasil pencarian artikel ditemukan beberapa artikel yang membahas penggunaan topikal seperti topikal insulin, gentamicin dan kolagen serta topikal epidermal semprot. Penggunaan topikal insulin dan topikal epidermal memberikan efek positif. Topikal tersebut efektif dalam mempercepat penyembuhan luka diabetes dibanding kelompok kontrol (Bhittani, Rehman, Altaf \& Altaf, 2020; Hwan et al., 2020). Akan tetapi, topikal gentamicin dan kolagen tidak memberikan efek yang signifikan. Hal ini dimungkinkan karena kelompok kontrol pada penelitian tersebut menggunakan perawatan luka lembab sementara penelitian lain menggunakan metode konvensional sebagai perbandingan. Meskipun tidak memberikan pengaruh signifikan tetapi penelitian tersebut memberikan informasi bahwa topikal tersebut (gentamicinkolagen dan moist) sama-sama berpengaruh dalam penyembuhan luka dan pengurangan ukuran luka diabetik (Uçkay et al., 2018)

Metode perawatan luka konvensional (wet-dry woundcare) telah diterapkan selama sekitar 2000 tahun. Perawatan luka konvensional merupakan perawatan luka menggunakan larutan normal saline $/ \mathrm{NaCl}$ $0,9 \%$ ditambah dengan iodine povidine kemudian ditutup dengan kasa kering (Meilin, Sidabutar, Patty, \& Simanjuntak, 2019). Akan tetapi, penelitian baru-baru ini menjelaskan bahwa metode modern wound dressing lebih efektif daripada metode konvensional (Nontji, Hariati, \& Arafat 2015; Rao, Pai, Hussein, Arun, \& Ram, 2012). Perawatan luka dengan metode moist balance/modern wound dressing lebih efektif karena jaringan dapat lebih cepat tumbuh pada kelembaban dan suhu yang sesuai (Meilin, Sidabutar, Patty, \& Simanjuntak, 2019).
Sementara itu, metode wet-dry menyebabkan luka kering dan akan membuat luka baru jika balutan diambil (Handayani, 2016). Studi meta analisis mengenai perbandingan modern wound dressing dan konvensional menyebutkan bahwa sebenarnya prinsip dari metode konvensional sama dengan metode modern, hanya saja penggunaan normal saline dan kassa saja lebih cepat mengering sehingga tidak dapat menjaga kelembapan permukaan luka (Handayani, 2016).

Penggunaan bahan modern dressing menurut artikel penelitian yang ditemukan seperti membran kolagen (Hwan et al., 2020), sukrosa (Edmonds et al., 2018) dan platelet plasma (Elsaid, Sameh, Mohamed, \& El-said, 2020). Hampir semua hasil penelitian memberikan informasi bahwa penggunaan bahan-bahan tersebut efektif untuk meningkatkan waktu penyembuhan luka diabetik. Rata-rata hasil penelitian menunjukan waktu penyembuhan dengan bahan tersebut lebih cepat dan pengurangan ukuran luka juga lebih besar.

Tiga artikel mengenai penggunaan kolagen untuk luka diabetik memberikan informasi yang sama bahwa bahan tersebut lebih efektif dibanding kelompok kontrol (Elsaid, Sameh, Mohamed, \& El-said, 2020; Volpe et al., 2020). Akan tetapi, ada salah satu dari 3 penelitian mengenai penggunaan platelet plasma memberikan informasi bahwa penggunaan platelet kaya plasma memberikan efek yang tidak signifikan dengan kelompok kontrolnya yaitu dressing steril, tetapi baik untuk mengontrol infeksi (Elsaid, Sameh, Mohamed, \& El-said, 2020).

Menurut sebagian besar review, tindakan penanganan pada luka tekan terdiri dari (1) wound management, (2) surgical management, serta (3) terapi 
Tabel 1. Identitas Artikel

\begin{tabular}{|c|c|c|}
\hline Penulis & Nama Jurnal & Kualifikasi Jurnal \\
\hline $\begin{array}{l}\text { Mujica, Orrego, Fuentealba, } \\
\text { Leiva, \& Zúñiga-hernández } \\
\text { (2019) }\end{array}$ & Journal of Diabetes Research & Pubmed \\
\hline $\begin{array}{l}\text { Niederauer, Michalek, \& } \\
\text { Armstrong (2017) }\end{array}$ & $\begin{array}{l}\text { Journal of Diabetes Science and } \\
\text { Technology }\end{array}$ & Pubmed \\
\hline $\begin{array}{l}\text { Zelen, Serena, Denoziere, \& } \\
\text { Fetterolf (2013) }\end{array}$ & International Wound Journal & Pubmed \\
\hline Zelen, Serena, \& Snyder (2014) & International Wound Journal & Pubmed \\
\hline Bianchi et al. (2019) & International Wound Journal & Proquest \\
\hline $\begin{array}{l}\text { Rao, Pai, Hussein, Arun, \& Ram } \\
\text { (2012) }\end{array}$ & $\begin{array}{l}\text { International Journal of Collaborative } \\
\text { Research on Internal Medicine \& Public } \\
\text { Health }\end{array}$ & Clinicalkey \\
\hline Park et al. (2019) & Diabetes Research and Clinical Practice & Clinicalkey \\
\hline Edmonds et al., (2018) & Lancet Diabetes Endocrinol & Clinicalkey \\
\hline $\begin{array}{l}\text { Omar, Alghadir, Al-Wahhabi, \& } \\
\text { Al-Askar (2014) }\end{array}$ & Diabetes Research and Clinical Practice & Clinicalkey \\
\hline Volpe et al. (2020) & Seminars in Vascular Surgery & Clinicalkey \\
\hline $\begin{array}{l}\text { Ahmed, Reffat, Hassan, \& } \\
\text { Eskander, (2020) }\end{array}$ & Clinical Research & Springerlink \\
\hline $\begin{array}{l}\text { Elsaid, Sameh, Mohamed, \& } \\
\text { El-said (2020) }\end{array}$ & World Journal Surgery & Springerlink \\
\hline Sorrentino et al., (2011) & $B M C$ Geriatrics & Springerlink \\
\hline Borys et al. (2018) & Endocrine & Springerlink \\
\hline Tantawy (2018) & $\begin{array}{l}\text { Laser in Medical Science } \\
\text { Lasers Medical Science }\end{array}$ & $\begin{array}{l}\text { Springerlink } \\
\text { Springerlink }\end{array}$ \\
\hline $\begin{array}{l}\text { Bhittani, Rehman, Altaf \& Altaf } \\
\text { (2020) }\end{array}$ & World Journal Surgery & Springerlink \\
\hline Uçkay et al. (2018) & BMC Infectious Diseases & Clinicalkey \\
\hline Park et al. (2019) & Diabetes Research and Clinical Practice & Clinicalkey \\
\hline $\begin{array}{l}\text { Megawati, Hakimi, \& } \\
\text { Sumaryani (2015) }\end{array}$ & Hospital Majapahit & SINTA 5 \\
\hline
\end{tabular}

Tabel 2. Matriks Sintesis

\begin{tabular}{|c|c|c|c|c|c|}
\hline Penulis & Material & $\begin{array}{l}\text { Sampel } \\
\text { Setting }\end{array}$ & Metode & Perbedaan & Hasil \\
\hline $\begin{array}{l}\text { Mujica, } \\
\text { Orrego, } \\
\text { Fuentealba, } \\
\text { Leiva, } \\
\text { Zúñiga- } \\
\text { hernández } \\
\text { (2019) }\end{array}$ & Propolis & $\begin{array}{c}31 \\
\text { Cili }\end{array}$ & RCT & Signifikan & $\begin{array}{l}\text { Pengurangan ukuran } \\
\text { luka pada kelompok } \\
\text { propolis lebih besar }\end{array}$ \\
\hline $\begin{array}{l}\text { Niederauer, } \\
\text { Michalek, \& } \\
\text { Armstrong } \\
(2017)\end{array}$ & $\begin{array}{l}\text { Oxygen } \\
\text { Therapy }\end{array}$ & $\begin{array}{c}100 \\
-\end{array}$ & RCT & Signifikan & $\begin{array}{lr}\text { Luka yang menutup } \\
\text { keseluruhan } \\
\text { kelompok perlakuan } \\
\text { lebih banyak }\end{array}$ \\
\hline $\begin{array}{l}\text { Zelen, Serena, } \\
\text { Denoziere, \& }\end{array}$ & $\begin{array}{l}\text { Membrane } \\
\text { Amniotic }\end{array}$ & $\begin{array}{c}25 \\
\text { Virginia }\end{array}$ & Komparatif & & $\begin{array}{l}\text { Perawatan luka dengan } \\
\text { membran amniotik }\end{array}$ \\
\hline
\end{tabular}




\begin{tabular}{|c|c|c|c|c|c|}
\hline Penulis & Material & $\begin{array}{l}\text { Sampel } \\
\text { Setting }\end{array}$ & Metode & Perbedaan & Hasil \\
\hline Fetterolf (2013) & & & & & $\begin{array}{lr}\text { memiliki } & \text { tingkat } \\
\text { penyembuhan } & \text { lebih } \\
\text { tinggi } & \end{array}$ \\
\hline $\begin{array}{ll}\text { Zelen, } & \text { Serena, } \\
\& & \text { Snyder } \\
(2014) & \end{array}$ & $\begin{array}{l}\text { Membrane } \\
\text { Amniotic }\end{array}$ & $\begin{array}{c}40 \\
\text { Virginia }\end{array}$ & $\mathrm{RCT}$ & Signifikan & $\begin{array}{lr}\text { Pemberian } & \text { membran } \\
\text { amniotik } & \text { setiap } \\
\text { minggu lebih efektif } \\
\text { daripada setiap } 2 \\
\text { minggu }\end{array}$ \\
\hline $\begin{array}{l}\text { Bianchi et al. } \\
(2019)\end{array}$ & $\begin{array}{l}\text { Membrane } \\
\text { Amniotic }\end{array}$ & $\begin{array}{c}237 \\
-\end{array}$ & $\mathrm{RCT}$ & Signifikan & $\begin{array}{l}\text { Perawatan dengan } \\
\text { membran amniotik } \\
\text { lebih efektif daripada } \\
\text { kelompok kontrol }\end{array}$ \\
\hline $\begin{array}{l}\text { Rao, Pai, } \\
\text { Hussein, Arun, } \\
\text { \& Ram (2012) }\end{array}$ & $\begin{array}{l}\text { Collagen } \\
\text { Dressing }\end{array}$ & $\begin{array}{c}100 \\
\text { Mangalore }\end{array}$ & Komparatif & Signifikan & $\begin{array}{l}\text { Kelompok dengan } \\
\text { collagen dressing lebih } \\
\text { cepat sembuh daripada } \\
\text { dengan perawatan luka } \\
\text { konvensional }\end{array}$ \\
\hline $\begin{array}{l}\text { Park et al. } \\
(2019)\end{array}$ & $\begin{array}{l}\text { Collagen } \\
\text { Dressing }\end{array}$ & $\begin{array}{l}30 \\
\text { Korea } \\
\text { Utara }\end{array}$ & $\mathrm{RCT}$ & Signifikan & $\begin{array}{l}\text { Waktu penyembuhan } \\
\text { kelompok collagen } \\
\text { dressing lebih cepat }\end{array}$ \\
\hline $\begin{array}{l}\text { Edmonds et al., } \\
\text { (2018) }\end{array}$ & $\begin{array}{l}\text { Sucrose } \\
\text { octasulfate } \\
\text { dressing }\end{array}$ & $\begin{array}{c}240 \\
\text { Prancis, } \\
\text { Jerman, } \\
\text { Italia, } \\
\text { Spanyol, } \\
\text { UK }\end{array}$ & $\mathrm{RCT}$ & Signifikan & $\begin{array}{l}\text { Waktu penutupan luka } \\
\text { pada kelompok control } \\
\text { dressing lebih lama } \\
\text { daripada kelompok } \\
\text { sucrose octasulfate }\end{array}$ \\
\hline $\begin{array}{l}\text { Omar, } \\
\text { Alghadir, Al- } \\
\text { Wahhabi, \& } \\
\text { Al-Askar } \\
\text { (2014) }\end{array}$ & $\begin{array}{c}\text { Shock wave } \\
\text { therapy }\end{array}$ & $\begin{array}{c}38 \\
\text { Saudi } \\
\text { Arabia }\end{array}$ & $\mathrm{RCT}$ & Signifikan & $\begin{array}{l}\text { Presentase penurunan } \\
\text { luka kelompok pada } \\
\text { kelompok perlakuan } \\
\text { lebih besar }\end{array}$ \\
\hline $\begin{array}{l}\text { Volpe et al. } \\
(2020)\end{array}$ & $\begin{array}{l}\text { Platelet-Rich } \\
\text { Plasma }\end{array}$ & $\begin{array}{c}56 \\
\text { Mesir }\end{array}$ & Komparatif & $\begin{array}{c}\text { Tidak } \\
\text { Signifikan }\end{array}$ & $\begin{array}{l}\text { Meskipun waktu } \\
\text { penyembuhan dan } \\
\text { pengurangan ukuran } \\
\text { luka tidak signifikan } \\
\text { tetapi pada kelompok } \\
\text { plasma lebih banyak } \\
\text { luka yang tidak infeksi }\end{array}$ \\
\hline $\begin{array}{l}\text { Ahmed, Reffat, } \\
\text { Hassan, \& } \\
\text { Eskander, } \\
(2020)\end{array}$ & $\begin{array}{l}\text { Platelet Rich } \\
\text { Plasma }\end{array}$ & $\begin{array}{c}24 \\
\text { Mansora }\end{array}$ & RCT & Signifikan & $\begin{array}{l}\text { Pengurangan diameter } \\
\text { luka maksimum pada } \\
\text { kelompok PRP lebih } \\
\text { besar }\end{array}$ \\
\hline $\begin{array}{l}\text { Elsaid, Sameh, } \\
\text { Mohamed, \& } \\
\text { El-said (2020) }\end{array}$ & $\begin{array}{l}\text { Cord Blood } \\
\text { Platelet Gel } \\
\text { Application }\end{array}$ & $\begin{array}{l}20 \\
-\end{array}$ & $\mathrm{RCT}$ & Signifikan & $\begin{array}{l}\text { Pengurangan ukuran } \\
\text { luka kelompok kontrol } \\
\text { lebih kecil daripada } \\
\text { kelompok perlakuan }\end{array}$ \\
\hline $\begin{array}{l}\text { Sorrentino et } \\
\text { al., (2011) }\end{array}$ & NPWT & $\begin{array}{l}2 \\
-\end{array}$ & quasy & Signifikan & $\begin{array}{l}\text { Penggunaan NPWT } \\
\text { meningkatkan } \\
\text { kecepatan granulasi } \\
\text { pada penutupan luka }\end{array}$ \\
\hline
\end{tabular}




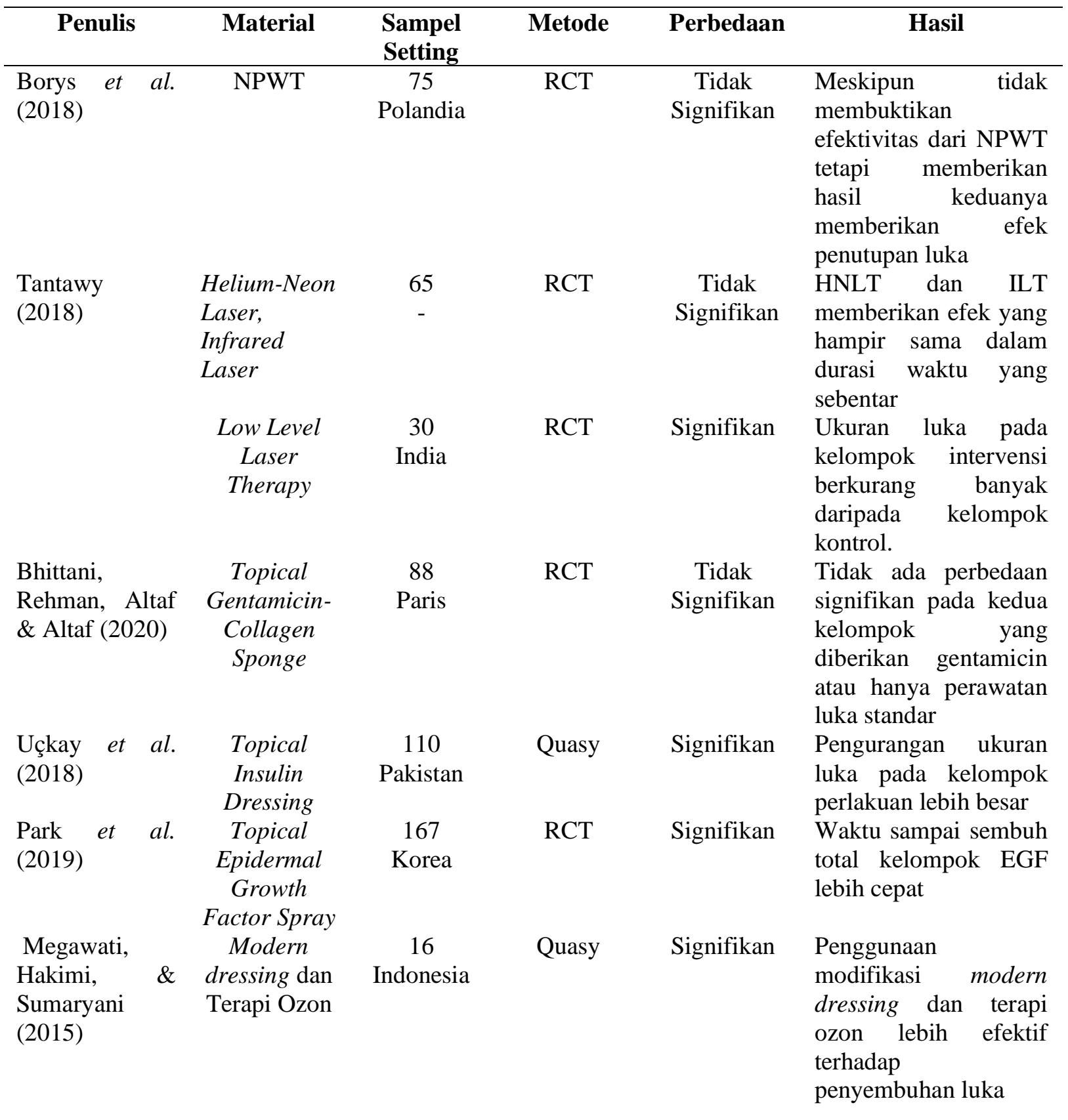

komplementer (Megawati, Hakimi, \& Sumaryani, 2015). Hal ini sesuai dengan hasil pencarian literatur pada penelitian ini. Didapatkan beberapa penelitian mengenai efektifitas penggunaan terapi komplementer yang ditambahkan pada metode modern dressing untuk penyembuhan luka diabetik.

Dari 20 artikel penelitian yang didapatkan mengenai manajemen perawatan luka diabetik, 14 diantaranya membahas keefektifan terapi adjuvant/komplementer yang ditambahkan pada perawatan luka modern untuk luka diabetik dan dari hasil penelitian tersebut didapatkan hasil bahwa terapi komplementer yang ditambahkan lebih efektif untuk menyembuhkan luka diabetik dibanding kelompok kontrol. Kelompok kontrol yang digunakan pada artikel penelitian tersebut dengan hanya 
menggunakan perawatan luka moderen atau konvensional saja.

Terapi komplementer yang ditambahkan untuk terapi luka diabetik menurut artikel yang ditemukan yaitu penggunaan gelombang shock therapy (Omar, Alghadir, Al-Wahhabi, \& AlAskar, 2014), tekanan negatif (Halimuddin, n.d.), laser helium-neon (Tantawy, 2018), laser dengan level rendah (Mathur, Sahu, Saraf, Patheja, \& Khan, 2017), terapi oksigen (Chen, Wu, Hsu, Hsieh, \& Chou, 2017), ozon terapi (Megawati, Hakimi, \& Sumaryani, 2015), dan penambahan bahan pelengkap sebagai dressing/topikal perawatan luka seperti propolis dan membran amniotic (Bianchi et al., 2019; Mujica, Orrego, Fuentealba, Leiva, \& Zúñiga-hernández, 2019; Zelen, Serena, Denoziere, \& Fetterolf, 2013). Sebagian besar hasil penelitian tersebut memberikan informasi bahwa terapi majamenen perawatan luka dengan komplementer lebih efektif untuk penyembuhan luka diabetik. Akan tetapi ada penelitian yang memberikan informasi bahwa efek dari penambahan terapi tidak berbeda signifikan yaitu pada penggunaan tekanan negatif dan laser helium-neon.

Namun, dua artikel penelitian yang ditemukan mengenai penambahan tekanan negatif untuk pengobatan luka diabetik bertolak belakang dengan penelitian di atas. Hal ini dikarenakan dua penelitian dengan metode yang berbeda, penelitian yang memberikan informasi penggunaan tekanan negatif efektif menggunakan metode quasi-experiment dengan tidak menggunakan kelompok kontrol. Sementara, pada penelitian kedua menggunakan metode randomized controlled trial dan kelompok kontrol dengan metode moisture (Borys et al., 2018; Sorrentino et al., 2011).

Keefektifan penambahan terapi komplementer dalam penyembuhan luka diabetik sesuai dengan penelitian sebelumnya mengenai efektivitas madu dan $\mathrm{NaCl}$ pada perawatan luka diabetik yang menunjukan bahwa perawatan luka dengan madu $+\mathrm{NaCl}$ lebih efektif daripada hanya dengan $\mathrm{NaCl}$ (Pramana, Suryani, \& Supriyono, 2012) Akan tetapi, penelitian lain yang dilakukan oleh Riani dan Fitri Handayani menunjukkan bahwa terapi modern wound healing saja lebih efektif daripada madu ditambah NaCL 0,9\% (Riani, 2017). Hal ini dimungkinkan karena sifat $\mathrm{NaCl} \quad 0,9 \%$ yang cepat menguap sehingga tidak dapat memberikan suasana lembab yang cukup lama sampai luka diganti kembali balutannya (Handayani, 2016).

Studi literatur lain menyebutkan bahwa modern dressing merupakan terapi yang paling efektif untuk penyembuhan luka diabetik. Meskipun modern dressing membutuhkan biaya lebih daripada metode konvensional, bukan berati penggunaan modern wound dressing tidak efektif (Mutiudin, 2019). Studi literature lain menyebutkan bahwa terdapat berbagai bahan alami yang dapat dijadikan sebagai CAM pada proses penyembuhan luka diabetik yaitu lidah buaya, madu, larva belatung, dan gula pasir (Prima, Andas, \& Ilyas, 2020).

Dari literatur yang telah ditelaah oleh peneliti memberikan gambaran bahwa penelitian mengenai penggunaan modern dressing untuk perawatan luka diabetes sudah berkembang pesat. Sementara, penggunaan metode konvensional sudah tidak terbukti efektif terlihat dari kelompok perbandingan yang digunakan. Metode modern yang dilengkapi dengan terapi komplementer memberikan pengaruh yang lebih signifikan dalam mempercepat penyembuhan luka diabetes.

\section{KESIMPULAN DAN SARAN}

Penelitian mengenai perawatan luka sudah berkembang pesat. Saat ini, perawatan luka yang paling efektif yaitu dengan metode modern dressing. Hampir semua hasil penelitian pada artikel yang 
telah ditelaah menunjukkan bahwa penggunaan modern dressing efektif untuk perawatan luka diabetes. Perawatan luka modern dressing dengan penambahan terapi komplementer menunjukan pengaruh yang lebih signifikan dalam mempercepat penyembuhan luka diabetik. Diharapkan rumah sakit dan klinik perawatan luka di Indonesia dapat menerapkan perawatan luka modern untuk pasien dengan luka diabetik dan peneliti selanjutnya dapat memperdalam penelitian mengenai penerapan perawatan luka metode modern di sarana kesehatan di Indonesia.

\section{DAFTAR PUSTAKA}

Adriani, A., \& Mardianti, T. (2016). Penggunaan balutan modern (hydrocoloid) untuk penyembuhan luka diabetes mellitus TIPE II. Jurnal Ipteks Terapan, 10(1), 18-24.

Ahmed, M., Reffat, S. A., Hassan, A., \& Eskander, F. (2020). Platelet-rich plasma for the treatment of clean diabetic foot ulcers. Annals of Vascular Surgery, 38, 206-211. doi: 10.1016/j.avsg.2016.04.023

Anggriani, S., Hariani., \& Dwiyanti, U. (2019). Efektifitas perawatan Luka modern dressing dengan metode moist wound healing pada ulkus diabetik di Klinik Perawatan Luka ETN Centre Makassar. Jurnal Media Keperawatan: Politeknik Kesehatan Makassar, 10(1), 19-24.

Bhittani, M. K., Rehman, M., Altaf, H. N., \& Altaf, O. S. (2020). Effectiveness of topical insulin dressings in management of diabetic foot ulcers. World Journal of Surgery, 44(6), 2028-2033. doi: 10.1007/s00268-01905321-3

Bianchi, C., Tettelbach, W., Istwan, N., Hubbs, B., Kot, K., Harris, S., \&
Fetterolf, D. (2019). Variations in study outcomes relative to intentionto-treat and per-protocol data analysis techniques in the evaluation of efficacy for treatment of venous leg ulcers with dehydrated human amnion/chorion membrane allograft. International Wound Journal, January, 761-767. doi: 10.1111/iwj.13094

Borys, S., Hohendorff, J., Koblik, T., Witek, P., Ludwig-Slomczynska, A. H., Frankfurter, C....Malecki, M. T. (2018). Negative-pressure wound therapy for management of chronic neuropathic noninfected diabetic foot ulcerations - short-term ef fi cacy and long-term outcomes. Endocrine, 62(3), 611-616. doi: 10.1007/s12020018-1707-0

Chen, C. Y., Wu, R.W., Hsu, M. C., Hsieh, C. J., \& Chou, M.C. (2017). Adjunctive hyperbaric oxygen therapy for healing of chronic diabetic foot ulcers: A randomized controlled trial. Journal Ostomy Cobtinence Nurses Society, 44(6), 536-45. doi: 10.1097/WON.0000000000000374

Edmonds, M., Lazaro-Martinez, J. L, Alfayate-Garcia, J. M., Martini, J., Petit, J., Rayman, G.... Piaggesi, A. (2018). Sucrose octasulfate dressing versus control dressing in patient with neuroischemic diabetic foot ulcer (explorer): An international, multicentre, double-blind, randomised, controlled trial. Lancet Diabetes Endocrinol, 6(3), 186-96. doi: 10.1016/S2213-8587(17)30438-

Elsaid, A., Sameh, M. E., Mohamed, E., \& El-said, M. (2020). Randomized controlled trial on autologous plateletrich plasma versus saline dressing in treatment of non-healing diabetic foot ulcers. World Journal of Surgery, 
44(4),

1294-1301.

doi: $10.1007 / \mathrm{s} 00268-019-05316-0$

Halimuddin. (n.d.). Pengaruh model aktivitas dan latihan intensitas ringan klien gagal jantung terhadap tekanan darah. Idea Nursing Journal, 3(3), 93-104.

Handayani, L. T. (2016). Studi meta analisis perawatan luka kaki diabetes dengan modern dressing. The Indonesian Journal of Health Science, 6(2), 149-159.

Hestiana, D. W. (2017). Faktor-faktor yang berhubungan dengan kepatuhan dalam pengelolaan diet pada pasien rawat jalan diabetes mellitus tipe 2 di Kota Semarang. Jurnal of Health Education, 2(2), 138-145.

Hwan, K., Hwan, S., Pio, J., Han, S., Lee, D., Soo, B. ... Woo, J. (2020). Topical epidermal growth factor spray for the treatment of chronic diabetic foot ulcers: A phase III. Diabetes Research and Clinical Practice, 142, 335-344.

doi:

10.1016/j.diabres.2018.06.002

Kristiyaningrum. (2013). Efektivitas penggunaan larutan $\mathrm{NaCl}$ dibandingkan dengan D40\% terhadap proses penyembuhan luka ulkus DM di RSUD KUDUS. Jurnal Ilmu Keperawatan dan Kebidanan (JIKK), 4(2), 52-58.

Kusumaningrum, N. S. D., \& Asriningati, R. (2016). Identifikasi risiko diabetic foot ulcer (DFU) pada pasien dengan diabetes mellitus. Jurnal Luka Indonesia, 2(1), 58-63.

Mathur, R. K., Sahu, K., Saraf, S., Patheja, P., \& Khan, F. (2017). Low-level laser therapy as an adjunct to conventional therapy in the treatment of diabetic foot ulcers. Lasers Medical Science, 32, 275-282. doi: 0.1007/s10103-016-2109-2

Megawati, V. N., Hakimi, H. M., \& Sumaryani, S. (2015). Efektifitas modifikasi modern dressing dan terapi ozon terhadap penyembuhan luka pada pasien dengan pressure ulcer di Wocare Clinic Bogor. Hospital Majapahit, 7(2), 11-20.

Meilin, A., Sidabutar, B., Patty, R. A., \& Simanjuntak, S. (2019). Gambaran pengetahuan perawat tentang perawatan luka modern dressing di satu rumah sakit swasta di Indonesia Barat. Jurnal Keperawatan Raflesia, 1(2), 77-86. doi: 10.33088/jkr.vli2.415

Mujica, V., Orrego, R., Fuentealba, R., Leiva, E., \& Zúñiga-hernández, J. (2019). Propolis as an adjuvant in the healing of human diabetic foot wounds receiving care in the diagnostic and treatment centre from the regional hospital of Talca. Journal of Diabetes Research, 2019, 1-10. doi: 10.1155/2019/2507578

Mutiudin, A. I. (2019). Efektivitas proses penyembuhan luka dengan penggunaan modern wound dressing pada pasien ulkus diabetik: a sistematik review. Jurnal Keperawatan \& Kebidanan, 3(2), 12 21.

Niederauer, M. Q., Michalek, J. E., \& Armstrong, D. G. (2017). A prospective, randomized, doubleblind multicenter study comparing continuous diffusion of oxygen therapy to sham therapy in the treatment of diabetic foot ulcers. Journal of Diabetes Science and Technology, 11(5), 883-891. 
Nontji, W., Hariati, S., \& Arafat, R. (2015). Teknik perawatan luka modern dan konvensional terhadap kadar interleukin 1 dan interleukin 6 pada pasien luka diabetik. Jurnal Ners, 10(1), 133-137.

Omar, M. T. A., Alghadir, A., AlWahhabi, K. K., \& Al-Askar, A. B. (2014). Efficacy of shock wave therapy on chronic diabetic foot ulcer: A single-blinded randomized controlled clinical trial. Diabetes Research and Clinical Practice, 106(3), 548-54. doi: 10.1016/j.diabres.2014.09.024.

Park, K. H., Kwon, J. B., Park, J. H., Shin, J. C., Han, S. H., \& Lee, J. W. (2019). Collagen dressing in the treatment of diabetic foot ulcer: A prospective, randomized, placebo-controlled, single-center study. Diabetes Research and Clinical Practice, 156, 107861.

Pramana, R. E., Suryani, M., \& Supriyono, M. (2012). Efektivitas pengobatan madu alami terhadap penyembuhan luka infeksi kaki diabetik (IKD) (Studi Kasus di Puskesmas Bangetayu dan Puskesmas Genuk Semarang). Stikes Telogorejo, Semarang.

Prima, A., Andas, A. M., \& Ilyas, A. S. (2020). Complementary alternative medicine (CAM) to promote wound healing in diabetic ulcers patient: a literature review.

Rao, H., Pai, A., Hussein, I., Arun, A., \& Ram, H. S. (2012). A comparative study between collagen dressings and conventional dressings in wound healing. International Journal of Collaborative Research on Internal Medicine \& Public Health, 4(5), 611624.
Riani. (2017). Perbandingan efektivitas perawatan luka modern "moist wound healing" dan terapi komplementer " $\mathrm{NaCl} 0,9 \%+$ madu asli" terhadap penyembuhan luka kaki diabetik derajat II di RSUD Bangkinang. Jurnal Ners Universitas Pahlawan Tuanku Tambusai, 1(2), 98-107.

Sorrentino, V. P., Corte, A. Della, Fattopace, A., Campitiello, F., Ferretti, M., \& Canonico, S. (2011). The use of negative pressure wound therapy (NPWT) and dermal substitutes in the treatment of diabetic foot ulcers. BMC Geriatrics, 11(Suppl 1), 2-3. doi: 10.1186/1471-2318-11S1-A39

Tantawy, S. A. (2018). A randomized controlled trial comparing heliumneon laser therapy and infrared laser therapy in patients with diabetic foot ulcer. Laser in Medical Science, 33(9), 1901-6. doi: 10.1007/s10103018-2553-2

Uçkay, I., Kressmann, B., Malacarne, S., Toumanova, A., Jaafar, J., Lew, D., \& Lipsky, B. A. (2018). A randomized, controlled study to investigate the efficacy and safety of a topical gentamicin-collagen sponge in combination with systemic antibiotic therapy in diabetic patients with a moderate or severe foot ulcer infection. BMC Infectious Diseases, $1-9$.

Volpe, P., Marcuccio, D., Stilo, G., Alberti, A., Foti, G., ... Massara, M. (2020). Efficacy of cord blood platelet gel application for enhancing diabetic foot ulcer healing after lower limb revascularization. Seminars in Vascular Surgery, 30(4), 106-112. doi:

10.1053/j.semvascsurg.2017.12.001 
World Health Organization. (2018). Diabetes mellitus. Geneva.

Zelen, C. M., Serena, T. E., Denoziere, G., \& Fetterolf, D. E. (2013). A prospective randomised comparative parallel study of amniotic membrane wound graft in the management of diabetic foot ulcers. International Wound Journal, 10(5), 502-7. doi: 10.1111/iwj.12097

Zelen, C. M., Serena, T. E., \& Snyder, R. J. (2014). A prospective, randomised comparative study of weekly versus biweekly application of dehydrated human amnion/chorion membrane allograft in the management of diabetic foot ulcers. International Wound Journal, 11(2), 122-128 doi.org/ 10.1111/iwj.12242 